JURNAL SEKRETARIS \& ADMINISTRASI BISNIS

Jurnal homepage http //jurnal asmtbac id/index php/jsab

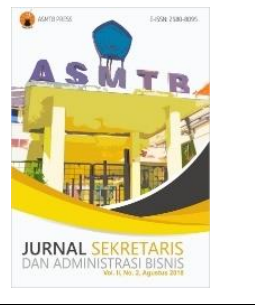

\title{
Opportunity Analysis of Construction Retail Business Using Approach Value Proposition
}

\section{Analisis Peluang Bisnis Ritel Konstruksi dengan Pendekatan Desain Proposisi Nilai}

Martin Senjaya Putra Utama ${ }^{1}$ and Kristina Sisilia ${ }^{2}$

${ }^{1,2}$ Prodi S1 Administrasi Bisnis, Fakultas Komunikasi dan Bisnis, Universitas Telkom

${ }^{1}$ martinspu@student.telkomuniversity.ac.id, ${ }^{2}$ kristina@ $@$ telkomuniversity.ac.id

\section{ARTICLE INFO}

Article history:

Received 8th March 2018

Received in revised form 9th May 2018

Accepted 18th August 2018

\section{Keywords:}

Canvas Value Proposition Design,

Fit and Gap,

Value Map,

Value Proposition,

Consumer's Profile

\begin{abstract}
The aims of this research are to find out the proposition value for Sumber Rizqie Abadi's (SRA) customers, to find out the customer's perceptions and expectations, to find out the result of value adjustment with customer's perceptions, and to find out the value proposition's role for SRA. This research is descriptive with qualitative approach. The techniques of collecting data are interview, observation, and documentation. This study implements design canvas value proposition taken from Alexander Osterwalder and Yves Pigneur to determine value proposition. This has the purpose to show the adjustment between value map from SRA and customer profile from SRA's segment. Therefore, the result of the adjustment is able to reduce the gap from SRA's value and customer perceptions value map as $S R A$ 's area have three parts namely products and services, gain creator, and pain relievers. Meanwhile, the customer profile as the costumer's area also has three parts, specifically jobs, gains, and pains. The results indicated that there are some gaps between the customer's perceptions and SRA's value. The gaps among others, the product quality same as the specification, the completeness of goods, supplying the industry needs, saving the money for building a dwelling, delivering the products to customers, and the products just available in SRA.
\end{abstract}

@ 2018 ASMTB PRESS

\section{Pendahuluan}

Indonesia sedang gencar-gencarnya melakukan pembangunan-pembangunan infrastruktur, menurut menteri koordinator perekonomian Darmin Nasution dalam detik finance menyatakan infratruktur Indonesia paling ketinggalan dan infrastruktur bukan sekedar pendorong ekonomi nasional namun sangat berpengaruh terhadap perkembangan antar daerah. Dalam market bisnis, proyeksi 2017 pada sektor konstruksi dan property diprediksi akan tumbuh lebih baik yang disebabkan oleh gencarnya pemeritah dalam pembangunan infratruktur yang ditunjukan dengan banyaknya pembangunan jalan tol dan jalan raya. Pembangunan jalan tol dalam kota, antar kota, maupun antar propinsi dan pembangunan jalan raya sebagai penghubung antar kota maupun dalam kota memungkinkan industri real estate atau properti bertumbuh dengan baik dan industri konstruksi sebagai pendukung pengembangan bisnis properti ikut tumbuh. 
Menurut Menko Darmin dalam okezone finance menyatakan bahwa perkembangan ritel di Indonesia tidak setinggi waktu-waktu yang lalu. Penurunan perkembangan ritel diikuti oleh pembangunan konstruksi yang semakin menurun terutama mall dikarenakan mall lah yang memfasilitasi banyak ritel. Perkembangan ritel memang sedang turun namun yang sedang tumbuh justru konsep stand alone komersial seperti merk makanan cepat saji. Salah satu contoh Mc Donald yang gencar-gencarnya memperbanyak tempatnya dengan menerapkan franchise, sehingga membutuhkan pembangunan tempat untuk beroperasi. Dari sisi bisnis property dan konstruksi tumbuh dengan baik yang ditunjukan oleh semakin meningkatnya kebutuhan dasar masyarakat seperti hunian berupa rumah dengan biaya yang sangat mahal, untuk mendapatkan satu unit rumah perlu mengeluarkan uang mencapai ratusan juta rupiah hingga miiaran.

Bisnis properti baik tanah maupun rumah bagi sebagian masyarakat dijadikan sebagai investasi, seperti contoh pengembangan dan pembangunan properti yang sedang besar besarnya yaitu Meikarta di Cikarang Utara dan Summarecon di Bandung yang sedang berkembang karena kebutuhan hunian rumah yang semakin meningkat. Dalam membangun properti yang dilakukan oleh pengembang baik kontraktor besar atau kecil dan berupa individu tentu diantaranya terdapat pemasok penyedia kebutuhan bahan untuk pembangunan hunian seperti bisnis bahan bangunan. Bisnis bahan bangunan memiliki jenisnya tersendiri besar maupun kecil tergantung dari segmen pelanggan mana yang mereka tuju. Seperti contoh bisnis bahan bangunan yang sudah besar seperti Depo Bangunan dan Mitra 10 memiliki ketersedian yang lengkap dan bermerk yang tidak dimilik oleh bisnis bahan bangunan kecil karena bisnis mereka didukung oleh ketersediaan dana investasi yang sangat besar dan sebagian merk telah bekerja sama dengan mereka, bisnis ini memiliki segmen pelanggan dengan ekonomi menengah ke atas dengan lokasi yang strategis dan berada di area perkotaan akan tetapi bisnis ini tidak menjangkau area-area yang jauh dari area perkotaan.

Bisnis bahan bangunan menyediakan segala jenis kebutuhan pembangunan rumah dan gedung baik kepada perusahaa konstruksi ataupun langsung kepada konsumen/pembeli rumah/gedung, Bisnis ini membutuhkan modal yang sangat besar untuk memulainya, akan tetapi tidak bila mampu melakukan kerjasama dengan para pemasok bahan atau material bangunan sehingga mampu mengurangi modal yang harus dikeluarkan, tentu tidak mudah dalam meyakinkan para pemasok untuk bekerja sama sehingga perlu meyakinkan para pemasok bahwa terdapat potensi bisnis untuk saling tumbuh.

Kemudahan dalam melakukan bisnis bahan material dikarenakan produk bersifat mampu bertahan lama dan awet/tidak mudah rusak, selain itu mampu dikatakan mudah bila lokasi sangat strategis yaitu berada dekat dengan kawasan perindustrian, pemukiman/ komplek masyarakat, area komersil pertokoan, dan area lahan pembukaan pembangunan perumahan. Bisnis tidak hanya sekedar menjual barang dan jasa kepada konsumen akan tetapi berpindah menjadi bagaimana membangun reputasi sehingga aktivitas bisnis menjadi mudah, bisnis perlu memiliki reputasi yang baik sehingga mampu menarik konsumen dan membuat konsumen berlangganan untuk membeli produk ditoko. Reputasi dapat dibangun melalui kualitas barang yang baik, menyediakan beranekaragam produk dengan merk yang telah dikenal, harga yang kompetitif dan pelayanan pelanggan yang ramah, cepat dan tepat serta fasilitas jasa pengantaran yang lebih rendah biaya. Pada era sekarang penjualan tidak hanya dilakukan melalui offline store atau toko melainkan sudah mulai memanfaatkan perkembangan tekonologi seperti internet untuk memaparkan semua produk yang tersedia, sehingga produk mampu diakses oleh banyak orang serta dapat dipesan dan dibeli melalui online atau langsung datang ke toko.

Bisnis ritel Sumber Rizqie Abadi (SRA) yang bergerak dibidang penjualan material bahan-bahan bangunan, bisnis ritel ini telah berdiri sejak tahun 2016, berlokasi di Kecamatan Klapanunggal, Kabupaten Bogor, SRA didirikan oleh Martin Senjaya Putra Utama sekaligus pemilik dari PT Agung Putra Jaya (APJ), pada awalnya SRA hanya tempat penyimpanan sementara yang dibuat untuk menunjang kegiatan bisnis APJ yang bergerak dibidang supplier atau pemasok barang. Dengan melihat prospek bisnis yang dirasa baik maka APJ memutuskan membuka gudang penyimpanan 
tersebut menjadi sebuah toko yang dibuka untuk umum dan diberi nama SRA.

SRA sebagai ritel bahan bangunan berada di antara pemukiman warga dan perindustrian, dengan lokasi yang strategis tersebut menjadkan peluang yang sangat besar dalam melakukan aktivitas bisnisnya. SRA sebagai ritel bahan bangunan yang baru merintis belum memiliki pasar yang luas sehingga jangkauan pelayanan yang diberikan tidak lebih dari $6 \mathrm{Km}$, akan tetapi tidak menutup kemungkinan untuk memperluas jangkauan pelayanan tergantung dari permintaan dari konsumen. Selain itu SRA memiliki produk yang bervariasi, berkualitas, dan lengkap sehingga memberikan konsumen pilihan dengan berbagai macam merk, produk bervariasi seperti pasir, split, bata merah, bata hebel $7 \mathrm{~cm}$ dan $10 \mathrm{~cm}$, semen holcim dan merah putih, paralon wavin dan power, besi, aksesoris pintu, mesin-mesin, cat dengan berbagai macam merek, dan masih banyak lagi produk dengan berbagai macam jenis dan merk yang tidak disebutkan.

Dengan produk yang bermerk dan berkualitas tentunya diikuti dengan harga yang mahal, akan tetapi dari segi harga SRA memberikan harga yang murah, sebagai contoh untuk produk semen holcim SRA memberikan harga Rp 50.000 dimana kompetitor sejenis memberikan harga Rp 51.000 - Rp 52.000 dengan selisih harga $\mathrm{Rp} 1.000$ - Rp 2.000, contoh lain untuk bata hebel dalam $1 \mathrm{~m}^{3}$ SRA memberikan harga Rp 600.000 sedangkan kompetitor sejenis memberikan harga Rp 620.000 dengan selisih harga Rp 20.000. Memang tidak seberapa untuk selisih harganya, akan tetapi apa bila membeli dengan kuantiti yang banyak maka akan terasa selisih perbedaan harga tersebut.

Karena berada dilingkungan masyarakat dan juga lingkungan indusrti, saat ini SRA telah melakukan kerjasama atau memilik langganan dengan beberapa segmen pemborong baik kontraktor maupun pribadi. Dengan kerjasama tersebut masing masing dari segmen memiliki kontribusi yang cukup besar dari segi pendapatan yang diperoleh, dimana untuk segmen pemborong kontraktor berkontribusi sampai dengan Rp 200 juta atau sebesar 50\% dan segmen pemborong individu berkontribusi sampai dengan Rp 80 juta atau sebesar 15\% dari pendapatan setiap bulannya. Selain kedua segmen tersebut masih terdapat segmen lain diluar pemborong yang hanya membeli produk sekali atau lebih seperti musiman dimana hanya membeli produk saat sedang ingin membangun rumahnya sendiri atau memperbaiki rumahnya sendiri, segmen ini bernama segmen residensial, segmen ini memiliki kontribusi sampai dengan Rp 120 juta atau sebesar 30\% dari pendapatan SRA. Berdasarkan besarnya persentase yang diberikan oleh segmen SRA dapat disimpulkan bahwa keuntungan yang diterima SRA selama 1.5 tahun terakhir sebesar Rp 720 juta atau 10\% dari total pendapatan yang diterima dari segmen SRA.

Untuk segmen pemborong seperti kontraktor biasanya tergantung kepada mereka memiliki pekerjan yang membutuhkan bahan bangunan atau tidak, akan tetapi biasanya ketika mereka membutuhkan bahan bangunan dan membeli bahan bangunan itu selalu dalam kapasitas yang besar. Sedangkan untuk segmen pemborong individu pun sama yaitu bergantung kepada ada atau tidaknya proyek pembangunan rumah, dan ketika mereka mendapatkanya maka pembelian pun dalam jumlah besar dari awal pekerjaan sampai dengan rumah selesai siap huni, selain itu segmen pemborong sebelum membeli produk pastinya melakukan survey harga apakah sesuai atau tidak, pelayanannya seperti apa, dan adakah potongan harga, sedangkan segmen residensial yang hanya sekali atau beberapa kali datang untuk membeli produk biasanya hanya sedikit menyesuaikan apa yang mereka butuhkan dan biasanya mereka terlalu selektif mengenai harga. Pola pembelian yang dilakukan tidak dapat ditentukan karena produk bahan bangunan bukanlah produk musiman, ketika para segmen pemborong mendapatkan proyek pembangunan rumah atau ketika segmen residensial membutuhkan produk maka saat itulah mereka membutuhkan bahan bangunan.

Dari segi jumlah pembelian, segmen residensial lah yang lebih banyak melakukan pembelian, pada dasarnya segmen ini membutuhkan bantuan seperti masukan mengenai produk karena tidak semua mengetahui apa kegunaan dari produk bahan bangunan tersebut. Sehingga pelayanan seperti 
membatu dan membimbing segmen ini dapat menenangkan kekhawatiran segmen itu sendiri, dengan memberikan pelayanan seperti itu membuat mereka datang kembali ke toko karena segmen tersebut menganggap bahwa itu dapat membantu mereka dan cenderung melupakan faktor harga yang sebelumnya mendominasi keputusan pembelian. Selain membantu dan membimbing mengenai kegunaan bahan bangunan, segmen ini cenderung tidak sabaran atau dapat dikatakan ketika mereka membeli produk maka produk harus dapat langsung mereka gunakan, pelayanan yang harus diberikan ialah dengan melakukan pengiriman yang cepat sehingga mereka dapat langsung menggunakan materialnya. Pengiriman cepat mampu menguntungkan konsumen seperti produk bisa langsung dipakai, bangunan cepat selsai dan lebih irit untuk membayar tukang karena biasanya tukang dibayar per hari.

Dari segi pembelian memang dapat dikatakan segmen residensial lah yang paling banyak, akan tetapi yang memberikan pendapatan terbesar adalah segmen peroyek, sehingga nilai pelayanan yang diberikan pun harus maksimal. Terdapatnya peluang untuk memperbesar pasar karena keberadaan industri atau kontraktor dan padatnya penduduk di sekitar area toko SRA sehingga terdapat kemungkinan untuk meningkatkan pendapatan SRA, oleh sebab itu perlu memfokuskan pemahaman mengenai segmen pelanggan SRA. Pemahaman karakteristik segmen akan memberikan insight dan informasi yang baru dan terbarukan mengenai kebutuhan mereka akan bahan bangunan, bagaimana mereka ingin dilayani dan bagaimana proses mereka memutuskan membeli dengan segala permasalahan dan harapan yang ingin dipuaskan. Jika insight dan informasi karakteristik segmen ini dapat diketahui dengan jelas maka SRA dapat menyesuaikan dan mendesain proposisi nilai bisnisnya terhadap segmen tersebut.

Dalam mendesain proposisi nilai alat yang digunakan dalam membantu mendesain ialah kanvas proposisi nilai oleh Osterwalder dan pigneur (2014). Kanvas proposisi nilia merupakan alat yang membantu mengobservasi dan memahami karakteristik konsumen dan memetakanya kedalam profil konsumen, lalu mendesain proposisi nilai yang telah dimiliki SRA untuk melayani segmen kedalam peta nilai. Harapan yang diinginkan ialah adanya keterkaitan antara peta nilai dan juga profil konsumen sehingga keterkaitan tersebut mampu mengurangi gap antara kebutuhan konsumen dengan proposisi nilai yang ditawarkan oleh SRA.

\section{Identifikasi Masalah}

Identifikasi masalah dalam penelitian ini yaitu, "Analisis Perencanaan Peluang Bisnis Pada Ritel Sumber Rizqie Abadi Dengan Pendekatan Kanvas Proposisi Nilai”. Selanjutnya, Identifikasi masalah tersebut dirinci kedalam beberapa pertanyaan penelitian, yaitu sebagai berikut:

1. Bagaimanakah Proposisi Nilai menciptakan nilai untuk konsumen ritel Sumber Rizqie Abadi?

2. Bagaimanakah Harapan dan Ekspektasi konsumen terhadap bisnis SRA?

3. Bagaimanakah Proposisi Nilai melakukan penyesuaian dengan Segmen Pasar ritel Sumber Rizqie Abadi?

4. Bagaimanakah Proposisi Nilai yang sesuai dengan harapan konsumen?

\section{Tujuan Penelitian}

Berdasarkan pada fokus penelitian dan identifikasi masalah yang telah diuraikan sebelumnya, maka tujuan dari penelitian ini adalah sebagai berikut:

1. Untuk mengetahui Proposisi Nilai menciptakan suatu nilai untuk konsumen ritel Sumber Rizqie Abadi.

2. Untuk Mengetahui Harapan dan Ekspektasi konsumen SRA.

3. Untuk mengetahui hasil dari penyesuaian Proposisi Nilai dengan segmen pasar SRA.

4. Untuk mengetaui Proposisi Nilai yang sesuai dengan harapan konsumen 


\section{Kajian Literatur}

Menurut Osterwalder dan Pigneur (2016:22) dalam Business Model Generation, Proposisi Nilai adalah alasan yang membuat pelanggan beralih dari satu perusahaan ke perusahaan lain serta dapat memecahkan masalah pelanggan atau memuaskan kebutuhan pelanggan. Kanvas Proposisi Nilai sebagai alat yang digunakan untuk mencocokan antara value map dengan profil konsumen dimana alat ini mampu memengaruhi seluruh blok dari bisnis model kanvas. Berikut gambar mengenai kanvas proposisi nilai dari Value Proposition Design (2014) oleh Alex Osterwalder dan Yves Pigneur

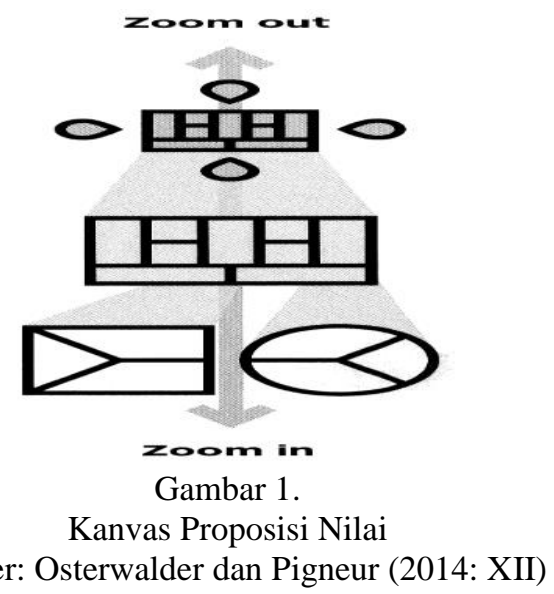

\section{Profil Konsumen}

Dalam mendapatkan pelanggan perusahaan harus mampu mengetahui karakteristik demografi pelanggan dan mengembangkan pemahaman yang lebih baik mengenai lingkungan, prilaku, kepedulian, dan aspirasi. Profil konsumen terdiri dari customer jobs, pains, and gains.

\section{1) Customer Jobs}

Berfikir bahwa konsumen ingin dapat menyelesaikan pekerjaannya atau tugasnya, pelanggan mencoba melakukan dan menyelesaikan tugas atau permasalahan yang ingin dipecahkan, sesuatu yang kita perspektifkan bahwa itu adalah hal terpenting tidak tentu penting untuk pelanggan. Pekerjaan pelanggan bdapat berupa tugas yang ingin dilakukan, masalah yang ingin diselsaikan dan kebutuhan yang ingingin dipuaskan, untuk dapat menemukan kesesuaian antara perusahaan dengan pelanggan harus dilakukan pengurutan atau pengelompokan berdasarkan hal yang biasa saja hingga hal yang sangat penting. Berikut adalah tabel mengenai tipe pekerjaan pelanggan.

Tabel 1.

Tipe Pekerjaan Pelanggan

\begin{tabular}{|c|c|}
\hline Tipe & Penjelasan \\
\hline Pekerjaan Fungsional & $\begin{array}{c}\begin{array}{c}\text { Ketika konsumen mencoba untuk melakukan atau menyelesaikan } \\
\text { tugas yang spesifik }\end{array} \\
\end{array}$ \\
\hline Pekerjaan Sosial & Ketika konsumen iningin terlihat baik atau mendapatkan pengakuan \\
\hline Pekerjaan Emosional & $\begin{array}{l}\text { Ketika konsumen melihat lihat keadaan spesifik apakah itu baik dan } \\
\text { aman. }\end{array}$ \\
\hline Pekerjaan Pendukung & $\begin{array}{l}\text { Konsumen melakukan pekerjaan pendukung didalam konteks } \\
\text { pembayaran dan penggunaan nilai, terdapat tiga peran dalam } \\
\text { membangun pekerjaan pendukung yaitu, pembeli nilai, pencipta } \\
\text { nilai, dan pengalihan nilai. }\end{array}$ \\
\hline Konteks Pekerjaan & $\begin{array}{l}\text { Pekerjaan pelanggan tergantung dari konteks spesifik yang akan } \\
\text { dilakukan. }\end{array}$ \\
\hline
\end{tabular}

Sumber: Value Proposition Design, Osterwalder dan Pigneur, 2014:12 
Dalam menentukan customer jobs terdapat beberapa pertanyaan pemicu untuk membantu memikirkan berbagai pekerjaan calaon pelanggan yang potensial (Osterwalder dan Pigneur, 2014:12).

a) Apa satu halutama yang tidak dapat dilakukan atau diselsaikan oleh pelanggan anda? Apa batu loncatan yang bisa membantu pelanggan anda mencapai dan menyelesaikan pekerjaan utama ini?

b) Apakah konteks/isi/jenis pekerjaan utama yang dimiliki konsumen seperti yang disebutkan di no 1 tadi itu berbeda? bagaimana aktivitas dan sasaran mereka berubah tergantung pada konteks yang berbeda ini?

c) Apa yang perlu dicapai oleh pelanggan anda yang melibatkan interaksi dengan orang lain?

d) Tugas apa yang ingin dilakukan pelanggan anda dalam pekerjaan atau kehidupan pribadi mereka? Masalah fungsional apa yang coba dipecahkan oleh pelanggan anda?

e) Apakah ada masalah yang menurut anda dimiliki pelanggan yang bahkan mungkin tidak mereka sadari?

f) Kebutuhan emosional apa yang ingin dipuaskan oleh pelanggan anda? Pekerjaan apa, jika selesai, akan memberi pelanggan anda rasa kepuasan diri?

g) Bagaimana keinginan pelanggan anda ingin dilihat/dianggap oleh orang lain? Apa yang dapat dilakukan pelanggan anda untuk membantu diri mereka dilihat/dianggap seperti ini?

h) Bagaimana keinginan perasaan pelanggan anda? Apa yang pelanggan anda perlu lakukan untuk merasa seperti ini?

i) Lacak interaksi pelanggan anda dengan produk atau layanan sepanjang masa pakaianya. Apa pekerjaan yang mendukung sepanjag masa penggunaan produk atau layanan tersebut? Apakah pengguna beralih peran selama proses ini?

\section{2) Customer Pains}

Rasa Sakit menjelaskna segala sesuatu yang mengganggu konsumen sebelum, sedang dan setelah mencoba untuk menyelesaiakan tugas. Rasa Sakit sendiri menjelaskan resiko, potensial hasil yang buruk, atau mendapatkan hasil yang buruk. Perusahaan harus mampu meminimalisir Rasa Sakit yang didapat oleh pelanggan, dalam meminimalisir Rasa Sakit perlu adanya tindakan pengurutan Rasa Sakit berdasarkan hal yang biasa saja hingga yang sulit. Rasa Sakit pelanggan memiliki tiga tipe yaitu hasil, permasalahn, karakteristik yang tidak diinginkan, hambatan, dan resiko, Berikut tabel mengenai karakteristik dari pains.

Tabel 2.

Tipe Rasa Sakit Pelanggan

\begin{tabular}{|c|c|}
\hline Tipe & Penjelasan \\
\hline $\begin{array}{c}\text { Hasil, Permasalahan, } \\
\text { Karakteristik yang Diinginkan }\end{array}$ & $\begin{array}{c}\text { Melibatkan berbagai hal yang tidak disukai oleh } \\
\text { pelanggan }\end{array}$ \\
\hline Hambatan & $\begin{array}{c}\text { Hal-hal yang mencegah dan menghambat pelangan } \\
\text { dalam mengerjakan pekerjaan }\end{array}$ \\
\hline Resiko & $\begin{array}{c}\text { Apa yang dapat membuat salah dan memperoleh } \\
\text { konsequensi negative yang penting }\end{array}$ \\
\hline
\end{tabular}

Sumber: Osterwalder dan Pigneur (2014:16)

Dalam menentukan customer pains terdapat beberapa pertanyaan pemicu untuk membantu memikirkan berbagai potensi rasa sakit pelanggan (Osterwalder dan Pigneur, 2014:15).

a) Bagaimana pelanggan anda mendefinisikan terlalu mahal? Apakah karena butuh banyak waktu, biaya menghabiskan terlalu banyak uang, atau membutuhkan upaya substansial/penting/ besar?

b) Apa yang membuat pelanggan anda merasa buruk? Apa yang membuatmereka frustasi, apa saja yang mengganggu mereka, atau hal-hal yang membuat mereka menjadi sakit kepala?

c) Bagaimana proposisi nilai yang ditawarkan saat ini yang dilakukan oleh pelanggan anda dengan tidak baik/tidak sesuai harapan/ target? Fitur apa/mana yang hilang menurut konsumen? Apakah ada masalah kinerja yang mengganggu mereka atau tidak berfungsi yang seperti mereka harapkan? 
d) Apa kesulitan dan tantangan utama yang dihadapi pelanggan anda? Apakah mereka mengerti bagaimana segala sesuatu bekerja/dikerjakan, apakah mengalami kesulitan menyelesaikan halhal tertentu, atau menolak pekerjaan tertentu untuk alasan tertentu?

e) Konsekuensi sosial negatif apa yang dihadapi atau ditakuti oleh pelanggan anda? Apakah mereka takut kehilangan muka, kekuasaan kepercayaan, atau status?

f) Resiko apa yang dikhawatirkan pelanggan Anda? Apakah mereka takut pada resiko finansial, sosial, atau teknis, atau apakah mereka bertanya kepada diri mereka sendiri apa yang sah?

g) Kesalahan-kesalahan umum atau kesalahan biasa apa saja yang dilakukan pelanggan Anda? Apakah mereka menggunakan solusi yang ada dengan cara yang salah?

h) Hambatan apa yang membuat pelanggan anda tidak dapat mengadopsi proposisi nilai dalam produk/ servis Anda? Adakah biaya investasi dimuka, kurangcepat memahami penggunanya, atau hambatan lain yang mencegah penggunaan proposisi nilai tersebut?

\section{3) Customer Gains}

Pencapaian mendeskripsikan hasil dan manfaat dari apa yang diinginkan oleh pelanggan, beberapa pencapaian didapatkan dari apa yang konsumen butuhkan, harapkan inginkan, dan yang tidak terbayangakan, perusahaan harus mampu membantu pelanggan mencapai apa yang diinginkan sehingga perusahaan memiliki nilai positif dimata pelanggan, Pencapaian Pelanggan yang terpenuhi menunjukan bahwa perusahaan telah berhasil menciptakan Proposisi Nilai karna dianggap mampu menjawab apa yang dibutuhkan oleh pelanggan. Berikut tabel mengenai empat tipe dari pencapaia pelanggan.

Tabel 3.

Tipe pencapaian konsumen

\begin{tabular}{|c|c|}
\hline Tipe & Penjelasan \\
\hline $\begin{array}{l}\text { Pencapaian yang } \\
\text { Dibutuhkan }\end{array}$ & $\begin{array}{l}\text { Pencapaian yang dibutuhkan adalah pencapaian tanpa solusi } \\
\text { yang tidak akan berhasil. }\end{array}$ \\
\hline $\begin{array}{l}\text { Pencapaian yang } \\
\text { Diharapkan }\end{array}$ & $\begin{array}{l}\text { Pencapaian yang mendasar dimana kita mengharapkan } \\
\text { pencapaian dari solusi. }\end{array}$ \\
\hline $\begin{array}{l}\text { Pencapaian yang } \\
\text { Diinginkan }\end{array}$ & Pencapaian yang melampaui apa yang diinginkan dari solusi. \\
\hline $\begin{array}{l}\text { Pencapaian yang Tidak } \\
\text { Terbayangkan }\end{array}$ & Pencapaian yang melampaui apayang diharapkan dan inginkan. \\
\hline
\end{tabular}

Dalam menentukan customer Gains terdapat beberapa pertanyaan pemicu untuk membantu memikirkan potensi keuntungan pelanggan yag berbeda (Osterwalder dan Pigneur, 2014:17).

a) Penghematan mana yang akan membuat pelanggan anda bahagia? Penghematan mana dari segi waktu, uang, dan usaha yang akan mereka hargai?

b) Tingkat kualitas apa yang mereka harapkan, dan apa yang akan mereka harapkan kurang lebih?

c) Bagaimana proposisi nilai saat ini dapat memuaskan pelanggan Anda? Fitur spesifik apa yang mereka sukai/ nikmati? Kinerja dan kualitas apa yang mereka harapakan?

d) Apa yang akan membuat pekerjaan atau kehidupan pelanggan anda menjadi lebih mudah? Mungkinkah ada kurva pembelanjaan yang lebih datar, tersedia lebih banyak layanan, atau biaya kepemilikan yang lebih rendah?

e) Apa konsekuensi positif secara sosial yang diinginkan pelanggan anda? Apa yang membuat mereka terlihat bagus/ baik? Apa yang dapat meningkatkan kekuatan atau status mereka?

f) Apa yang paling dicari pelanggan? Apakah mereka mencari desain yang bagus, jaminan, fitur spesifik atau lebih banyak fitur?

g) Apa yang pelanggan impikan? apa yang ingin mereka capai, atau apa yang akan sangat melegakan mereka?

h) Bagaimana pelanggan anda engukur keberhasilan dan kegagalan? bagaimana mereka mengukur kinerja atau biaya? 
i) Apa yang akan meningkatkan kemungkinan menambah pelanggan anda untuk mengadopsi proposisi nilai yang ditawarkan bisnis Anda? Apakah mereka menginginkan biaya lebih rendah, investasi kurang, resiko rendah, atau kualitas yang lebih baik?

\section{Value Map}

\section{1) Products and Services}

Produk dan jasa harus dapat melengkapi fungsional, social, dan emosi dari planggan atau mampu membantu memuaskan kebutuhan dasar pelanggan, sangat penting untuk mengakui bahwa tidak semua produk dan jasa memiliki kesamaan yang relevan untuk pelanggan, beberapa produk dan jasa sangat penting unutk untuk Proposisi Nilai dan beberapa baik untuk dimiliki. (Osterwalder, Pigneur, 2014:29).

Penyampaian produk dan jasa tidak semata-mata hanya mengirimkan produk dan diperoleh oleh pelanggan, tetapi menyampaikan produk dan jasa yang mampu diterima oleh pelanggan, artinya bahwa produk dan jasa yang kita kirimkan kepada pelanggan mampu membantu atau menyelesaikan pekerjaan pelanggan.

\section{2) Pain Relievers}

Pereda Rasa Sakit mendeskripsikan bagaimana produk dan jasa yang dimiliki mamupu mengurangi rasa sakit yang dialami oleh pelanggan, rasa sakit mampu dihilankan dan dikurangi dari segala sesuatu yang mengganggu ketika pelanggan belum, sedang, atau telah mencoba untuk menyelesaikan tugas, Pereda Rasa Sakit dan Rasa Sakit Pelanggan harus sesuai atau harus mampu menjawab permasalahan yang ada (Osterwalder, Pigneur, 2014:31).

Dalam arti lain penciptaan Proposisi Nilai harus mampu menjawab segala kesulitan atau kebutuhan dari Segmen Pasar, sehingga nantinya Proposisi Nilai yang di buat dapat tersampaikan dengan baik dan menghilangkapan Rasa Sakit dari Segmen Pasar atau pelanggan.

\section{3) Gain Creators}

Menciptakan Keuntungan mendeskripsikan bahwa produk dan jasa dapat memberi keuntungan pada pelanggan, dengan tegas bagai mana perusahaan bermaksud untuk menghasilkan hasil dan manfaat apa yang diharapan dan diinginan oleh pelanggan, atau memberikan sesuatu yang berbeda seperti fungsi utilitas, keuntungan social, emosi positif, dan harga yang rendah (Osterwalder, Pigneur, 2014:33).

Mencipakan Keuntungan tidak saja hanya melihat dari segi perusahaan dimana perusahaan mampu selalu mendapatkan untung yang besar, melainkan perusahaan harus melihat apakah produk dan jasa yang perusahaan tawarkan mampu memberikan keuntungan untuk konsumen atau tidak.

\section{Metode Penelitian}

Jenis penelitian yang digunakan ini adalah penelitian deskriptip dengan menggunakan pendekatan kualitatif. Fokus pada penelitian telah ditetapkan berdasarkan tujuan penelitian. Jenis penelitian ini adalah deskriptif dengan pendekatan kualitatif. Teknik pengumpulan data yang dilakuakan menggunakan wawancara, observasi, dan dokumentasi. Penelitian ini menggunakan desain kanvas proposisi nilai oleh Alexander Osterwalder dan Yves Pigneur untuk menentukan proposisi nilai dan tahapan penelitian. Instrumen penelitian adalah peneliti sendiri. Teknik dalam menguji keabsahan data peneliti menggnakan triangulasi. Lokasi penelitian di toko bahan bangunan SRA, Cileungsi, Bogor. Lamanya penelitian selama empat minggu, wawancara dilakukan diminggu pertama dan kedua, observasi dilakukan diminggu pertama sampai dengan minggu keempat, dokumentasi dilakukan diminggu kedua sampai keempat. 


\section{Hasil dan Pembahasan}

\section{A. Karakteristik Informan}

Penelitian yang dilakukan oleh peneliti mengenai bisnis ritel konstruksi pada SRA tentunya memiliki karakteristik informan dalam melakukan pengumpulan data sehingga data yang dihasilkan mampu membantu peneliti dalam merumuskan proposisi nilai. Karakteristik informan yang dituju oleh peneliti ialah informan yang mengerti akan situasi dan keadaan dari SRA dan toko bahan bangnan lainnya, mengetahui berbagai macam produk, telah melakukan pembelian lebih dari dua toko ritel bahan bangunan sehingga mengetahui perbedaan antara keduanya dan melakukan kegiaata bisnis atau pekerjaannya selalu berkaitan dengan bahan bangunan.

Sesuai dengan subjek, dalam mengumpulkan informasi peneliti menggunakan berbagai macam informan yang dimana telah dibahas pada bab sebelumnya, informan yang dituju adalah pemilik bisnis dan segmen pemborong kontrktor. Berikut tabel mengenai biodata dari informan:

Tabel 4.

Karakteristik Informan

\begin{tabular}{|c|c|c|c|c|c|c|}
\hline No & Nama & $\begin{array}{c}\text { Usia } \\
\text { (Tahun) }\end{array}$ & Pekerjaan & Alamat & $\begin{array}{c}\text { Aktor } \\
\text { Penelitian }\end{array}$ & Keterangan \\
\hline 1 & H. Abas & 46 & $\begin{array}{c}\text { Wiraswast } \\
\text { a }\end{array}$ & $\begin{array}{c}\text { Kp. Narogong. } \\
\text { Kec. } \\
\text { Klapanunggal }\end{array}$ & $\begin{array}{c}\text { Pemilik } \\
\text { SRA }\end{array}$ & Pemilik \\
\hline 2 & $\begin{array}{c}\text { PT. Restu } \\
\text { Agung }\end{array}$ & 23 & $\begin{array}{c}\text { Kontraktor } \\
\text { Jasa } \\
\text { Narogong }\end{array}$ & $\begin{array}{c}\text { Kp. Narogong. } \\
\text { Kec. } \\
\text { Klapanunggal }\end{array}$ & $\begin{array}{c}\text { Segmen } \\
\text { Pemborong } \\
\text { Kontraktor }\end{array}$ & $\begin{array}{c}\text { Telah bekerjasama dengan SRA dari awal SRA } \\
\text { berdiri dan rata-rata memberikan pemasukan } \\
\text { sebesar lebih dari Rp 200 jt, serta dalam } \\
\text { kegiatan bisnisnya mayoritas membutuhkan } \\
\text { bahan bangunan }\end{array}$ \\
\hline 3 & PT. Truba & 45 & $\begin{array}{c}\text { Kontraktor } \\
\text { Jasa } \\
\text { Pembangu } \\
\text { nan }\end{array}$ & $\begin{array}{c}\text { Kp. Sindang } \\
\text { Lengo, Kec. } \\
\text { Klapanunggal }\end{array}$ & $\begin{array}{c}\text { Segmen } \\
\text { Pemborong } \\
\text { Kontraktor }\end{array}$ & $\begin{array}{c}\text { Telah bekerjasama dengan SRA selama lebih } \\
\text { dari 1 tahun serta dalam kegiatan bisnisnya } \\
\text { mayoritas membutuhkan bahan bangunan }\end{array}$ \\
\hline
\end{tabular}

Sumber: Diolah oleh Peneliti

Dalam menentukan hasil, peneliti menggunakan metode desain proposisi nilai untuk memperoleh nilai nilai yang mampu diciptakan oleh sebuah bisnis dengan menyesuaikan keingginan dari segmen pelanggan, desain ini terbagi menjadi dua bagian yaitu peta nilai dan profil konsumen. Peta nilai terdiri dari products and services, pains reliever, dan gain creator, peta nilai didapat dari hasil wawancara dengan owner SRA dengan mengajukan pertanyan megenai nilai-nilai yang telah dimiliki oleh SRA. Dalam penentuan dan penciptaan peta nilai terdapat beberapa langkah (1) mendata produk dan layanan yang tersedia, (2) sketsakan pereda rasa sakit yang diberikan bisnis, (3) sketsakan pencapaian yang telah dibuat pada bisnis, dan (4) beri nilai terhadap ketiganya berdasarkan dari yang terpenting sampai yang tidak penting.

Peneliti pun melakukan wawancara kepada pemilik dari SRA untuk menannyakan seputar nilai-nilai apa yang diberika oleh SRA kepada para konsumen dan memastikan bahwa hasil observasi telah sesuai dengan nilai-nilai yang ditawarkan SRA kepada konsumen. Hasil wawancara mengenai nilainilai yang ditawarkan SRA kepada konsumen dan menyesuaikan hasil dari observasi, sehingga hasil 
observasi bisa menjadi tambahan informasi yang tidak disebutkan oleh pemilik mengenai nilai-nilai yang diberika oleh SRA. Berikut nilai-nilai yang ditawarkan SRA dari hasil observasi dan wawancara:

1) Menawarkan harga yang murah.

2) Promo dan Diskon.

3) Produk berkualitas dengan menyediakan produk yang setandar SNI walaupun ukuran tidak sesuai.

4) Memberikan pelayanan yang baik seperti pengiriman barang yang cepat.

5) Garansi pengembalian.

6) Memberikan informasi menggenai kegunaan suatu produk.

Tabel 5.

Nilai-Nilai yang telah Ada pada SRA

\begin{tabular}{|c|c|}
\hline NO & Nilai-Nilai Existing \\
\hline 1 & Memberikan harga yang murah \\
\hline 2 & Memberikan promo dan diskon kepada pelanggan yang melakukan pembelian \\
& banyak \\
\hline 3 & Layanan yang baik seperti cepat tanggap dan juga layanan pengantaran produk \\
\hline 4 & $\begin{array}{c}\text { Produk berkualitas dengan menyediakan produk yang standar SNI walaupun ukuran } \\
\text { tidak sesuai }\end{array}$ \\
\hline 5 & Pengiriman yang cepat \\
\hline 6 & Garansi pengembalian dan penukaran \\
\hline 7 & Produk yang bermerk dan beragam untuk memberikan pilihan kepada pelanggan \\
\hline 8 & Memberikan informasi terkait produk dan menyarankan produk kepada pelanggan \\
\hline
\end{tabular}

Sumber: Diolah oleh Peneliti

Profil konsumen terdiri dari jobs, pains, and gains, profil konsumen didapat dari hasil wawancara dengan segmen kontraktor dengan mengajukan pertanyaan mengenai harapan, kekhawatiran, dan kebutuhan pelanggan. Dalam penentuan profil konsumen terdapat beberapa langkah (1) pilih segmen pelanggan yang ingin dituju, (2) identifikasikan segala sesuatu yang ingin dilakukan oleh pelanggan, (3) identifikasikan keresahan-keresahan pelanggan terhadap bisnis, (4) identifikasikan harapan pelanggan terhadap bisnis dan (5) prioritaskan jobs, pains and gains dari yang terpenting hingga tidak penting. Berikut gambar mengenai poin-poin dari hasil mengolah informasi dari hasil wawancara dengan segmen SRA. 
Tabel 6.

Pengurutan Poin-Poin Pernyataan Informan

\begin{tabular}{|c|c|c|c|c|c|c|c|}
\hline $\mathbf{A}$ & \multicolumn{2}{|c|}{ PT. Restu Agung Narogong } & \multicolumn{2}{|l|}{ PT Truba } & \multirow{2}{*}{$\begin{array}{c}\text { E } \\
\text { Total } \\
\text { Ranking }\end{array}$} & \multirow{2}{*}{$\begin{array}{c}\text { F } \\
\text { Jobs/Pains/ } \\
\text { Gains }\end{array}$} & \multirow{2}{*}{$\frac{\text { G }}{\text { Urutan }}$} \\
\hline No & Jawaban & Ranking & Jawaban & Ranking & & & \\
\hline 1 & $\begin{array}{l}\text { Memiliki pekerjaan seperti } \\
\text { membuat atau memperbaiki } \\
\text { bangunan, jalan, dan hunian }\end{array}$ & 4 & $\begin{array}{l}\text { Memiliki pekerjaan seperti } \\
\text { membuat atau memperbaiki } \\
\text { bangunan, jalan, dan hunian }\end{array}$ & 4 & 4 & Jobs & 1 \\
\hline & $\begin{array}{c}\text { Memastikan suatu produk ada } \\
\text { atau tersedia }\end{array}$ & 2 & & & 2 & Jobs & 3 \\
\hline 2 & & & $\begin{array}{c}\text { Menanyakan harga bahan } \\
\text { bangunan }\end{array}$ & 3 & 3 & Jobs & 2 \\
\hline 3 & - & - & - & - & - & - & - \\
\hline 4 & $\begin{array}{c}\text { Ketersediaan bahan bangunan } \\
\text { yang tentunya akan } \\
\text { mempengaruhi pekerjaan }\end{array}$ & 3 & Ketersediaan bahan bangunan & 3 & 3 & Pains & 3 \\
\hline & & & $\begin{array}{c}\text { Jarak toko yang jauh dari lokasi } \\
\text { pekerjaan }\end{array}$ & 2 & 2 & Pains & 6 \\
\hline 5 & $\begin{array}{c}\text { Terdapat barang yang sulit untuk } \\
\text { dicari }\end{array}$ & 3 & & & 3 & Pains & 4 \\
\hline
\end{tabular}

\begin{tabular}{|c|c|c|c|c|c|c|c|}
\hline A & \multicolumn{2}{|c|}{ PT Restu Agung Narogong } & \multicolumn{2}{c|}{ PT Truba } & E & F & G \\
\hline N0 & Jawaban & Ranking & Jawaban & Ranking & $\begin{array}{c}\text { Total } \\
\text { Ranking }\end{array}$ & $\begin{array}{c}\text { Jobs/Pains/ } \\
\text { Gains }\end{array}$ & Urutan \\
\hline 6 & - & - & - & - & - & - & - \\
\hline 7 & $\begin{array}{c}\text { Kelengkapan dan ketersediaan } \\
\text { bahan bangunan }\end{array}$ & 4 & & 4 & Gains & 1 \\
\hline 8 & $\begin{array}{c}\text { Ketersediaan bahan bangunan } \\
\text { yang selalu siap ada }\end{array}$ & 4 & $\begin{array}{c}\text { Suppot dari toko bahan } \\
\text { bangunan }\end{array}$ & 3 & 3 & Gains & 3 \\
\hline & & & $\begin{array}{c}\text { Support yang baik dari toko } \\
\text { bahan bangunan }\end{array}$ & 3 & 3 & Gains & 3 \\
\hline & & & $\begin{array}{c}\text { Kualitas barang yang sesuai } \\
\text { dengan spesifikasi }\end{array}$ & 3.5 & 3.5 & Gains & 1 \\
\hline
\end{tabular}




\begin{tabular}{|c|c|c|c|c|c|c|c|}
\hline A & \multicolumn{2}{|c|}{ PT Restu Agung Narogong } & \multicolumn{2}{|l|}{ PT Truba } & \multirow{2}{*}{$\begin{array}{c}\text { E } \\
\text { Total } \\
\text { Ranking }\end{array}$} & \multirow{2}{*}{$\begin{array}{c}\text { F } \\
\text { Jobs/Pains/ } \\
\text { Gains }\end{array}$} & \multirow{2}{*}{$\begin{array}{c}\text { G } \\
\text { Urutan }\end{array}$} \\
\hline NO & Jawaban & Ranking & Jawaban & Ranking & & & \\
\hline 9 & $\begin{array}{c}\text { Produk yang dipesan tidak ada } \\
\text { dan tidak sesuai dengan } \\
\text { spesifikasi }\end{array}$ & 4 & $\begin{array}{c}\text { Ketersediaan produk yang } \\
\text { minim dan tidak sesuai dengan } \\
\text { spesifikasi }\end{array}$ & 3 & 3.5 & Pains & 3 \\
\hline & & & $\begin{array}{c}\text { Jarak pekerjaan jauh dari lokasi } \\
\text { toko bahan bangunan }\end{array}$ & 2 & 2 & Puins: & 5 \\
\hline & & & $\begin{array}{c}\text { Menyelesaikan pekerjaan } \\
\text { melebihi batas waktu yang telah } \\
\text { ditentukan }\end{array}$ & 4 & 4 & Pains & 1 \\
\hline 10 & $\begin{array}{c}\text { Menggunakan produk khusus } \\
\text { industri }\end{array}$ & 3 & $\begin{array}{c}\text { Menyediakan produk khusus } \\
\text { industri }\end{array}$ & 3 & 3 & Gains & 5 \\
\hline 11 & $\begin{array}{c}\text { Ketersediaan produk yang kurang } \\
\text { lengkap }\end{array}$ & 3 & & & 3 & Puins: & 3 \\
\hline 12 & $\begin{array}{c}\text { Kesalahan biasanya toko } \\
\text { memberikan produk yang tidak } \\
\text { sesuai dengan spesifikasi }\end{array}$ & 3 & $\begin{array}{l}\text { Lupa dalam memberikan contoh } \\
\text { atau sample }\end{array}$ & 1 & 2 & Pains: & 6 \\
\hline
\end{tabular}

\begin{tabular}{|c|c|c|c|c|c|c|c|}
\hline $\mathbf{A}$ & \multicolumn{2}{|c|}{ PT Restu Agung Narogong } & \multicolumn{2}{|l|}{ PT Truba } & \multirow{2}{*}{$\begin{array}{c}\text { E } \\
\text { Total } \\
\text { Ranking }\end{array}$} & \multirow{2}{*}{$\begin{array}{c}\text { Fobs/Pains/ } \\
\text { Gains }\end{array}$} & \multirow{2}{*}{$\begin{array}{c}\text { G } \\
\text { Urutan }\end{array}$} \\
\hline No & Jawaban & Ranking & Jawaban & Ranking & & & \\
\hline 13 & $\begin{array}{c}\text { Waktu pengerjaan melebihi dari } \\
\text { yang diperkirakan }\end{array}$ & 4 & $\begin{array}{c}\text { Waktu pengerjaan tidak sesuai } \\
\text { dengan apa yang telah } \\
\text { direncanakan }\end{array}$ & 4 & 4 & Pains & 1 \\
\hline & $\begin{array}{c}\text { Kekuatan bangunan yang kurang } \\
\text { dikarenakan kualitas produk yang } \\
\text { kurang }\end{array}$ & 4 & & & 4 & Pains & 2 \\
\hline 14 & Kelengkapan produk & 4 & Kelengkapan produk & 4 & 4 & Gains & 1 \\
\hline & $\begin{array}{l}\text { Produk langsung dikirim } \\
\text { ketempat yang telah dipesan }\end{array}$ & 3.5 & $\begin{array}{l}\text { Mampu mengirimkan produk } \\
\text { langsung ketempat proyek }\end{array}$ & 3.5 & 3.5 & Gains & 3 \\
\hline & Pengiriman produk cepat & 3 & Pengiriman yang cepat & 3 & 3 & Gains & 3 \\
\hline & & & $\begin{array}{l}\text { Kualitas barang bagus dan } \\
\text { sesuai dengan spesifikasi }\end{array}$ & 4 & 4 & Gains & 2 \\
\hline & & & $\begin{array}{c}\text { Respon yang cepat terhadap } \\
\text { permintaan }\end{array}$ & 3 & 3 & Gains & 6 \\
\hline & & & $\begin{array}{l}\text { Selalu memberikan informasi } \\
\text { update mengenai harga barang }\end{array}$ & 2 & 2 & Gains & 7 \\
\hline
\end{tabular}




\begin{tabular}{|c|c|c|c|c|c|c|c|}
\hline $\bar{A}$ & \multicolumn{2}{|c|}{ PT Restu Agung Narogong } & \multicolumn{2}{|l|}{ PT Truba } & $\mathrm{E}$ & $F$ & G \\
\hline NO & Jawaban & Ranking & Jawaban & Ranking & $\begin{array}{l}\text { Total } \\
\text { Ranking }\end{array}$ & $\begin{array}{c}\text { Jobs/Pains/ } \\
\text { Gains }\end{array}$ & Urutan \\
\hline 15 & $\begin{array}{l}\text { Kualitas yang sesuai dengan } \\
\text { spesifikasi yang diminta }\end{array}$ & 4 & $\begin{array}{c}\text { Sesuai dengan spesifikasi yang } \\
\text { diminta }\end{array}$ & 4 & 4 & Gains & 2 \\
\hline 16 & $\begin{array}{l}\text { Kualitas dan pelayanan yang } \\
\text { dicarisaat membeli produk }\end{array}$ & 3.5 & Pelayanan yang diberikan & 3 & 3.25 & Gains & 3 \\
\hline 17 & $\begin{array}{l}\text { Pelayanan pengiriman yang baik } \\
\text { seperto pengiriman yang cepat }\end{array}$ & 3 & Pengirimanyang cepat & 3 & 3 & Gains & 3 \\
\hline 18 & $\begin{array}{c}\text { Kualitas dan pelayanan yang } \\
\text { dierikan }\end{array}$ & 3.5 & $\begin{array}{c}\text { Kualitas yang sesuai dengan } \\
\text { spesifikasi dan pelayanan yang } \\
\text { baik }\end{array}$ & 4 & 3.75 & Gains & 2 \\
\hline & & & Harga murah & 1 & 1 & Gains & 8 \\
\hline
\end{tabular}

Sumber: Diolah oleh Peneliti

Tabel 7.

Persepsi Segmen Kontraktor

\begin{tabular}{|c|c|}
\hline NO & Kegiatan Segmen Kontraktor $(\mathrm{Jobs})$ \\
\hline 1 & Memiliki pekerjaan seperti membuat atau memperbaiki bangunan dan jalanan \\
\hline 2 & Memastikan suatu produk ada atau tersedia \\
\hline 3 & Menanyakan harga bahan bangunan \\
\hline
\end{tabular}

\begin{tabular}{|c|c|}
\hline NO & Harapan Segmen Kontraktor (Gains) \\
\hline 1 & Respon cepat terhadap permintaan \\
\hline 2 & Pekerjaan selsai tepat waktu \\
\hline 3 & Kualitas yang sesuai dengan spesifikasi \\
\hline 4 & Mampu mengirimkan produk langsung ketempat proyek \\
\hline 5 & Menyediakan produk industri \\
\hline 6 & Harga yang murah \\
\hline 7 & Ketersediaan dan kelengkapan bahan bangunan \\
\hline 8 & Memberikan informasi update mengenai suatu produk \\
\hline
\end{tabular}

\begin{tabular}{|c|c|}
\hline NO & Keresahan Segmen Kontraktor (Pains) \\
\hline 1 & Toko memberikan produk yang tidak sesuai dengan spesifikasi \\
\hline 2 & Terdapat barang yang sulit dicari \\
\hline
\end{tabular}




\begin{tabular}{|c|c|}
\hline 3 & Jarak pekerjaan jauh dari lokasi toko bahan bangunan \\
\hline 4 & Kekuatan bangunan yang kurang karena kurangnya kualitas \\
\hline 5 & Menyelesaikan pekerjaan melebihi waktu yang telah ditentukan \\
\hline 6 & Ketersedian produk yang kurang lengkap \\
\hline
\end{tabular}

Sumber: Diolah oleh Peneliti

Setelah peta nilai dan profil konsumen ditentukan buatlah kecocokan atau fit antara keduanya untuk mengurangi gap antara keinginan dan harapan pelanggan dengan nilai yang terlah diciptakan SRA. Pencocokan yang dilakuakan antara products and services pada peta nilai dicocokan dengan jobs pada profil konsumen, pain relievers pada peta nilai dengan pains pada profil konsumen, dan gain creator pada peta nilai dengan gains pada profil konsumen. Profil konsumen pada kedua segmen residensial dan pemborong di satukan sehingga menjadi satu profil konsumen agar nilai dapat diciptakan tanpa adanya pemisahan segmen. Berikut gambar kecocokan peta nilai dengan profil konsumen.

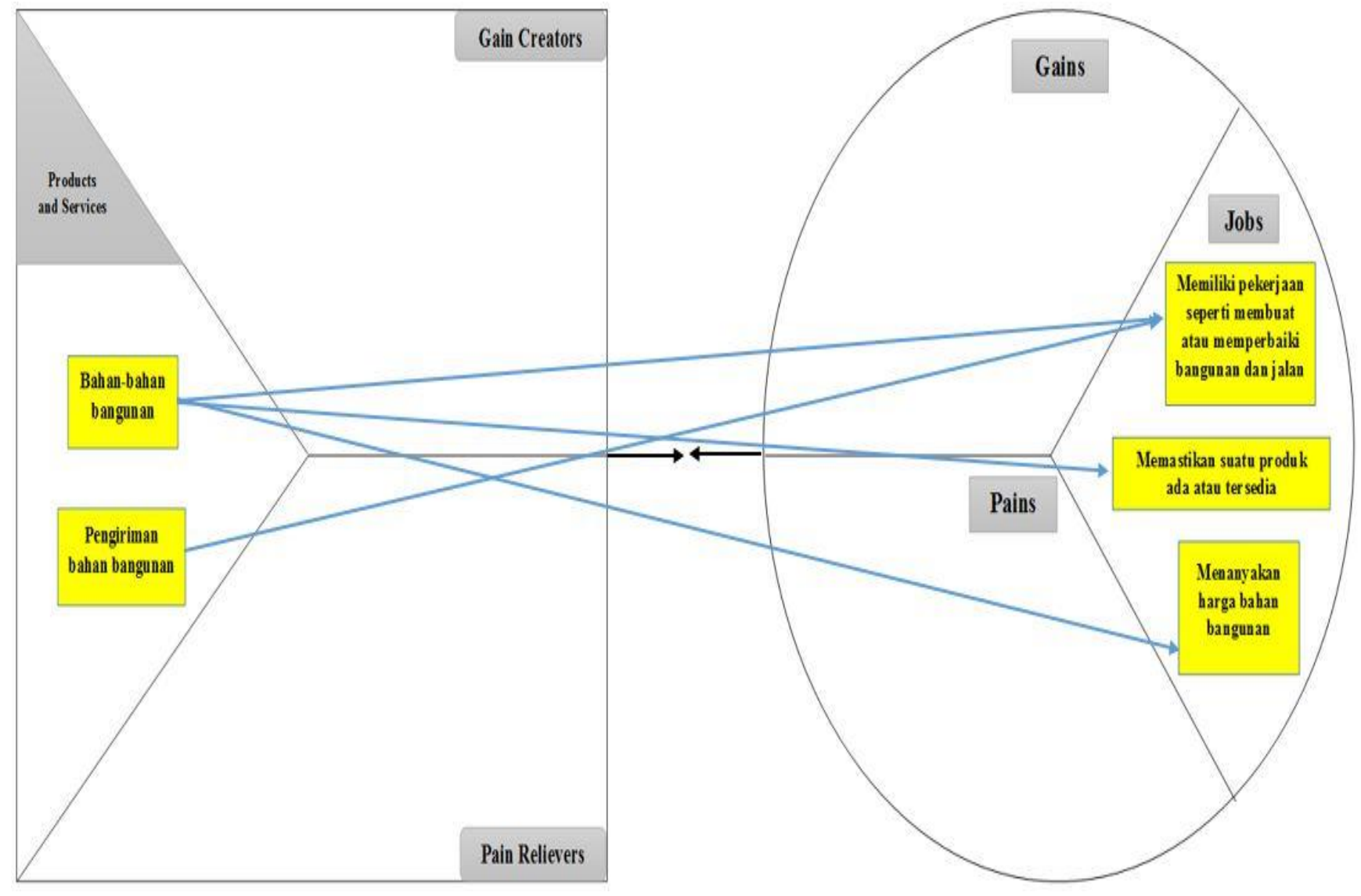



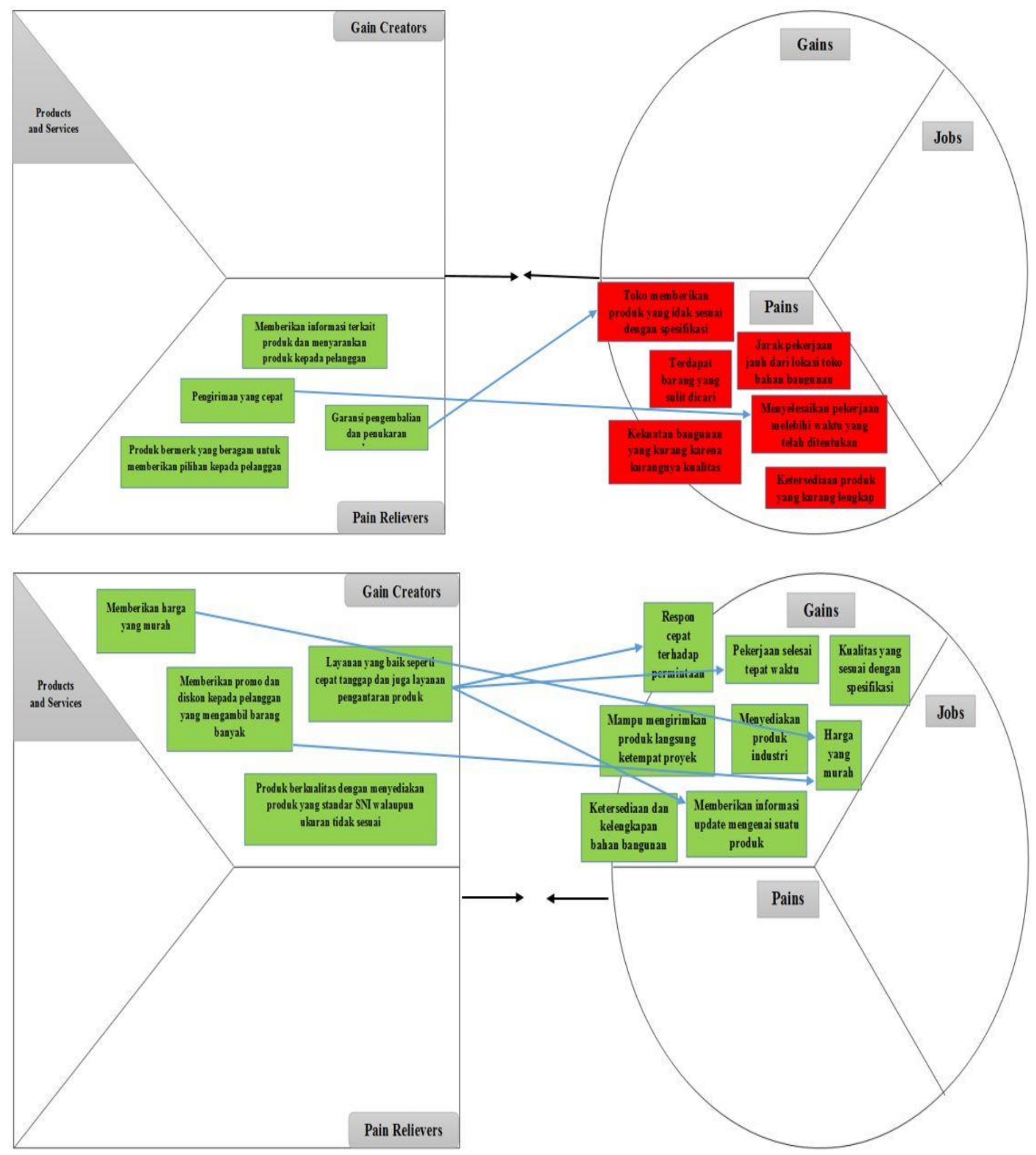
PETA NILAI

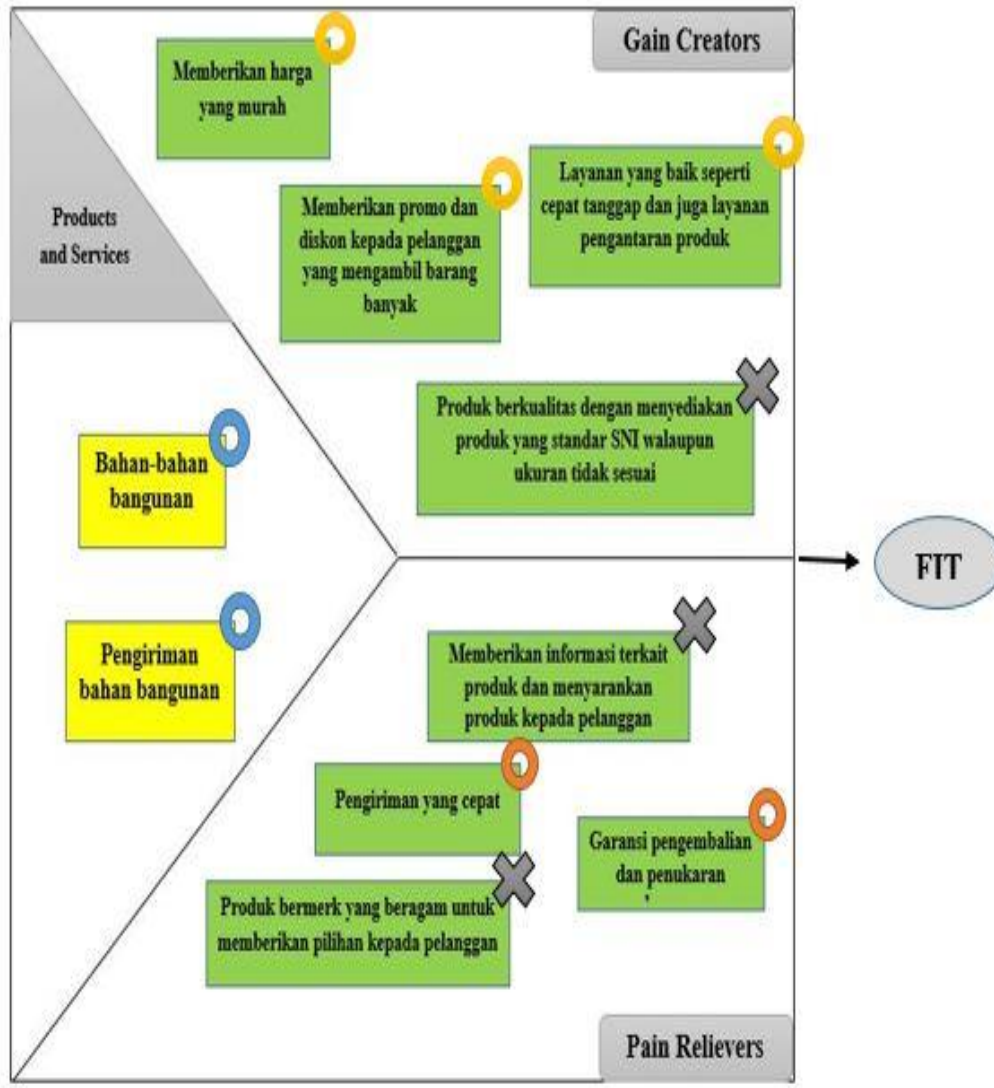

Gambar 2.

Fit antara Peta Nilai dan Profil Konsumen

Sumber: Diolah oleh Peneliti

\section{PROFIL KONSUMEN}

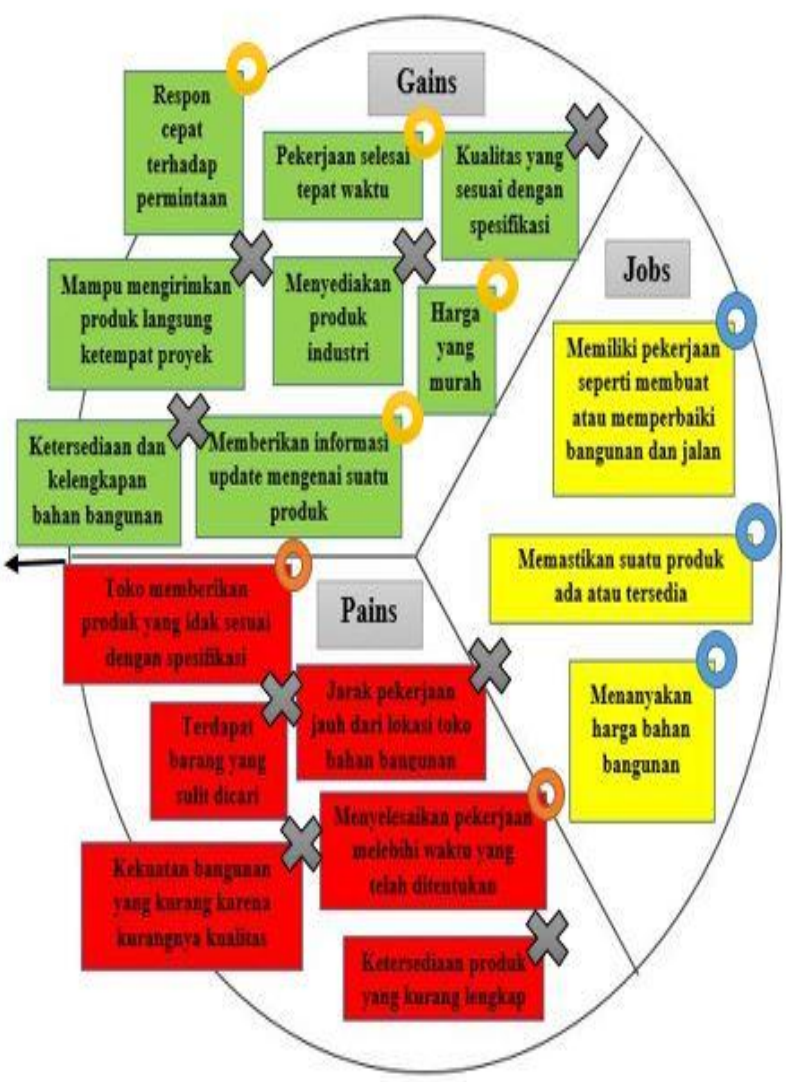

Berikut kesenjangan antara nilai yang dimiliki SRA dengan harapan, keinginan, dan kekhawatiran segmen SRA:

1) Menyediakan produk industri.

2) Kualitas yang sesuai dengan spesifikasi.

3) Kelengkapan dan ketersediaan bahan baku.

4) Dapat mengirimkan produk ketempat yang diinginkan atau langsung ke proyek.

5) Jarak pekerjaan yang jauh dari toko bahan bangunan.

6) Terdapat barang yang sulit dicari.

7) Ketersediaan produk yang kurang lengkap dan tidak sesuai spesifikasi.

8) Kekuatan bangunan kurang karena kualitas barang yang jelek

Setelah kesenjangan ditentukan carilah cara agar kesenjangan tersebut dapat diminimalisir atau dapat teratasi, berikut usulan cara yang dibrikan peneliti. 
Tabel 8.

Usulan Pemenuhan Gap Gains

\begin{tabular}{|c|c|c|}
\hline NO & Gap & Usulan \\
\hline 1 & $\begin{array}{c}\text { Menyediakan produk } \\
\text { industri }\end{array}$ & \multirow{3}{*}{$\begin{array}{l}\text { Membuat pelayanan pengadaan barang, } \\
\text { maksudnya dengan keterbatasan biaya yang } \\
\text { dimiliki bila melengkapi produk kebutuhan bahan } \\
\text { bangunan semua baik segmen residensial dan } \\
\text { pemborong tentunya memerlukan dana yang } \\
\text { banyak, untuk meminimalkannya yaitu melengkapi } \\
\text { produk yang sering dicari dan dibeli oleh konsumen } \\
\text { dan mencari pesanan barang sehingga produk } \\
\text { industri dan spesifikasi sesuai dengan permintaan. }\end{array}$} \\
\hline 2 & $\begin{array}{l}\text { Kualitas yang sesuai } \\
\text { dengan spesifikasi }\end{array}$ & \\
\hline 3 & $\begin{array}{l}\text { Kelengkapan dan } \\
\text { ketersediaan bahan baku }\end{array}$ & \\
\hline 4 & $\begin{array}{c}\text { Dapat Mengirimkan } \\
\text { produk ketempat yang } \\
\text { diinginkan atau langsung } \\
\text { ke proyek }\end{array}$ & $\begin{array}{l}\text { Dapat mengirimkan produk ketempat yang } \\
\text { diinginkan, karena untuk menciptakan nilai yang } \\
\text { baik di benak konsumen bahwa SRA mampu } \\
\text { mensupport dalam pekerjaan akan tetapi sesuai } \\
\text { dengan syarat yang ditentukan. }\end{array}$ \\
\hline
\end{tabular}

Sumber: Diolah oleh Peneliti

Tabel 9.

Usulan Pemenuhan Gap Pains

\begin{tabular}{|c|c|c|}
\hline NO & GAP & Usulan \\
\hline 1 & $\begin{array}{l}\text { Jarak pekerjaan yang jauh } \\
\text { dari toko bahan bangunan }\end{array}$ & $\begin{array}{l}\text { Melayani pengantaran barang walaupun lokasi } \\
\text { pekerjaan yang jauh dan masih dalam cakupan } \\
\text { SRA dan sesuai dengan syarat yang ditentukan. }\end{array}$ \\
\hline 2 & $\begin{array}{c}\text { Terdapat barang yang sulit } \\
\text { dicari }\end{array}$ & $\begin{array}{c}\text { Membantu mencari barang yang diminta untuk } \\
\text { membantu dalam mencari kebutuhan yang } \\
\text { diinginkan dan agar terciptanya hubungan kerja } \\
\text { sama yang baik antara SRA dengan segmen } \\
\text { kontraktor }\end{array}$ \\
\hline 3 & $\begin{array}{l}\text { Ketersediaan produk yang } \\
\text { kurang lengkap dan tidak } \\
\quad \text { sesuai spesifikasi }\end{array}$ & \multirow{2}{*}{$\begin{array}{l}\text { Bila menjual semua produk maka memerlukan } \\
\text { biaya yang sangat besar, dengan menjual produk } \\
\text { bermerk yang beragam untuk memberikan } \\
\text { pilihan kepada konsumen dan sering digunakan } \\
\text { atau ditanyakan oleh konsumen akan membantu } \\
\text { dalam melengkapi kebutuhan konsumen dan } \\
\text { kualitas yang baik karena menggunakan produk } \\
\text { yang bermerk atau dikenal oleh orang banyak. }\end{array}$} \\
\hline 4 & $\begin{array}{l}\text { Kekuatan bangunan } \\
\text { kurang karena kualitas } \\
\text { barang yang jelek }\end{array}$ & \\
\hline
\end{tabular}




\section{Simpulan}

Berdasarkan hasil penelitian dan analisis yang dilakukan peneliti, dapat diambil beberapa kesimpulan yang dapat mengidentifikasi masalah pada penciptaan nilai oleh SRA sehingga nilai yang ingin diberikan pad pelanggan mampu dirasakan oleh pelanggan itu sendiri. Kesimpulan yang didapat dari penelitian sebagai berikut:

Tabel 10.

Nilai Ideal Untuk SRA

\begin{tabular}{|c|c|}
\hline No. & Nilai yang Ideal \\
\hline 1 & Memberikan harga yang murah \\
\hline 2 & Memberikan promo dan diskon kepada pelanggan yang melakukan pembelian banyak \\
\hline 3 & Layanan yang baik seperti cepat tanggap dan juga layanan pengantaran produk \\
\hline 4 & Produk berkualitas dengan menyediakan produk yang standar SNI walaupun ukuran tidak \\
& sesuai \\
\hline 5 & Pengiriman yang cepat \\
\hline 6 & Garansi pengembalian dan penukaran \\
\hline 7 & Memberikan informasi terkait produk dan menyarakan produk kepada pelanggan \\
\hline 8 & Membuat pelayanan pengadaan barang \\
\hline 9 & menyediakan barang yang sering ditanyakan dan digunakan konsumen \\
\hline 10 & Mroduk bermerk yang beragam untuk memberikan pilihan kepada pelanggan dan \\
\hline 11 & Membantu mencari barang yang dibutuhkan \\
\hline 12 & Sengiriman barang walaupun lokasinya yang jauh \\
\hline
\end{tabular}

Sumber: Diolah oleh Peneliti

\section{Ucapan Terima Kasih}

Puji syukur peneliti ucapkan kehadirat Allah SWT atas limpahan rahmat dan karunia-Nya sehingga peneliti dapat menyelesaikan penelitian yang berjudul "Analisis Perencanaan Peluang Bisnis Ritel Konstruksi dengan Menggunakan Pendekatan Kanvas Proposisi Nilai” dengan lancar. Dalam proses penelitian ini, peneliti mendapatkan begitu banyak bantuan, baik berupa bimbingan, dorongan, semangat, motivasi, dan doa dari berbagai pihak. Oleh karena itu, peneliti ingin mengucapkan terima kasih yang sebesar-besarnya kepada Ibu Kristina Sisilia dan Ibu Trisha Gilang Saraswati, serta seluruh informan yang telah meluangkan waktu dan membantu peneliti dalam mengumpulkan informasi-informasi yang digunakan dalam penelitian ini. 


\section{Referensi}

Ahmadi, R. (2014). Metodologi Penelitian Kualitatif. Yogyakarta: Ar-ruza Media

Creswell, J.W. (2014) Research Design Pendekatan Kualitatif, Kuantitatif, dan Mixed - Cetakan 4. Yogyakarta: Pustaka Pelajar.

Herdiansyah, H. (2015). Wawancara, Observasi, dan Focus Group Sebagai Instrumen Penggalian Data Kualitatif - Cetakan 2. Jakarta: PT Rajagrafindo Persada

Indrawati. (2015). Metode Penelitian Manajemen dan Bisnis - Konvergensi Teknologi Komunikasi dan Informasi. Bandung: PT Refika Aditama

Osterwalder, A., \& Pigneur, Y. (2016). Business Model Generation - cetakan 10. Jakarta: PT Elex Gramedia.

Osterwalder, A., \& Pigneur, Y. (2014). Value Proposition Design. New Jersey: John Wiley \& Sons, Inc.

Sugiyono. (2013). Metode Penelitian Kuantitatif, Kualitatif, dan R\&D - cetakan 18. Bandung: Alfabeta

Yusuf, M.A. (2016). Metode Penelitian Kuantitatif, Kualitatif, \& Penelitian Gabungan - cetakan 3. Jakarta: Prenadamedia Group.

Detikfinance. (2017). Jokowi Gencar Bangun Infrastruktur Hingga 2019, Ini Alasannya. Diambil dari: $\quad$ https://finance.detik.com/berita-ekonomi-bisnis/3416678/jokowi-gencar-banguninfrastruktur-hingga-2019-ini-alasannya. (Akses: 20 November 2017).

Okezonefinance. (2017). Perkembangan Bisnis Ritel Tidak Setinggi Masa Lalu. Diambil dari: https://economy.okezone.com/read/2017/06/26/320/1724919/menko-darmin-perkembanganbisnis-ritel-tidak-setinggi-masa-lalu. (Akses: 20 November 2017).

Simamora, N.S. (2016). Sektor Konstruksi dan Properti Bakal Jadi Primadona. Diambil dari: http://market.bisnis.com/read/20161222/192/614525/proyeksi-2017-sektor-konstruksi-danproperti-bakal-jadi-primadona. (Akses: 20 November 2017). 